\section{Artificial Billiard Balls}

In his 1859 book The Game of Billiards, Michael Phelan, co-owner of the Phelan \& Collender Company, the largest manufacturer of billiard balls in the United States, lamented the state of his raw material supply. The ivory obtained from the tusks of the elephants of Ceylon, he said, was superior to that of the African elephant for his purposes, being more solid and less friable. However, the cost of this ivory was "dreadfully dear." Adding to the problem was the fact that only 1 in 50 tusks was of sufficient quality to make a billiard ball, due to the defects-pores and cracks-inherent in natural materials. Phelan speculated that "if any inventive genius would discover a substitute for ivory, possessing those qualities which make it valuable to the billiard player, he would make a handsome fortune for himself, and earn our sincerest gratitude."

Several years later, the decimation of elephant herds had created such a shortage of ivory that Phelan decided to supply the small fortune himself. In advertisements placed in newspapers across the United States, he offered a prize of $\$ 10,000$ to anyone who could make artificial billiard balls.

John Wesley Hyatt, a young printer in Albany, N.Y., began experimenting with the material he was most familiar withthe natural polymer cellulose, a carbohydrate obtained from the cell walls of plants and a common ingredient in paper and textiles. He was soon fashioning composite balls made of wood pulp, cloth, and paper bound together by adhesives such as shellac and various resins, compressed into a sphere under high temperature and pressure. He patented such a ball in 1865, but it did not have the same hardness and "feel" as the ivory balls that billiards players were accustomed to, so it was unsuccessful.

Fortunately, the occurrence of one of those serendipitous spills that happen frequently in the history of science led to a breakthrough for Hyatt. As a printer, he naturally had a supply of collodion, which printers used to coat their fingertips to prevent burns from hot lead type. Collodion was a compound of ether, alcohol, and cellulose nitrate, invented by Louis Menard of the Collège de France in 1846, which produced a clear liquid that hardened into a tough transparent film. Menard had been trying-unsuccessfully-to synthesize the explosive cellulose trinitrate, or "guncotton." The side product, collodion, proved to be useful to doctors as a compound to close minor cuts and to printers like Hyatt for burn prevention; it also served as a coating for photographic plates.

One day in 1868, Hyatt found that a bottle of collodion in his cabinet had spilled, and that a hard, thick, transparent material had formed. He thought collodion might make an excellent coating for his billiard balls. In his excitement, he convinced his brother Isaiah Smith Hyatt, until then a newspaper editor, to join him in his experimentation.

\section{"[Phelan] offered a prize of \\ $\$ 10,000$ to anyone who could make artificial billiard balls."}

After months of coating numerous variations of their composite billiard balls with collodion without success, they began experimenting with the primary raw material of collodion itself-cellulose nitrate. Alexander Parkes and Daniel Spill of England had patented a material composed of cellulose nitrate, vegetable oil, and solvents called "Parkesine" in 1865. Parkesine was a white, plastic dough that could be pressed into molds, extruded into shapes, and carved by hand when hardened. The gentlemen's efforts to market this material failed, probably due to a lack of business acumen.

Soon the Hyatt brothers, no doubt aware of the work done by Parkes and Spill, were making billiard balls from their own version of this hardened cellulose nitrate dough coated with collodion. However, real world testing of the product revealed one major flaw. Due to its close chemical similarity to guncotton, "a lighted cigar applied would at once result in a serious flame and occasionally the violent contact of the balls would produce a mild explosion like a percussion guncap," Hyatt wrote. "We had a letter from a billiard saloon proprietor in Colorado, mentioning this fact and saying that he did not care so much about it but that instantly every man in the room pulled a gun."

More experimentation revealed that what Parkes had considered a minor additive - camphor oil obtained from the laurel tree on the island of Formosa-was actually a key solvent in producing a more workable, stable material. The new camphor-stabilized compound was named "celluloid," for "cellulose-like," by Isaiah Hyatt. Because it could be remelted and used over again, celluloid was the first thermoplastic material invented. In the 1870s, the brothers estab- lished the Albany Billiard Ball Company, and also the Albany Dental Plate Company-although this effort was occasionally plagued by reports of exploding dentures by cigar smokers and complaints about the taste of camphor that the dentures retained. The Hyatts later combined both companies to form the Celluloid Manufacturing Company. They never submitted their billiard balls to the Phelan \& Collender Company for consideration for the $\$ 10,000$ prize, however, and it is probable that the money was never awarded.

The Hyatts sold their billiard balls through agents such as the Brunswick Billiards Company, a maker of fine billiards tables, and achieved some success in that area. But celluloid soon proved to have other, higher-volume, uses. An engineer named Charles Burroughs invented various machines to produce celluloid in standard bar sizes; he also developed a planer to slice it into thin sheets, which eventually led to the production of film for the motion picture industry. From 1870 on, celluloid was used mostly for women's corset clasps and hair combs, and as collars and cuffs for men's shirts. Middle-class men who could not afford to change shirts often changed the collars or cuffs to maintain appearances. Celluloid offered them what one manufacturer advertised as "waterproof linen" that could be wiped clean with a wet sponge. The addition of dyes and other process changes allowed manufacturers to mimic tortoiseshell or mother of pearl for women who did not have the means to afford the genuine material.

John Wesley Hyatt soon ventured into other areas, establishing the Hyatt Pure Water Company in 1881 and the Hyatt Roller Bearing Company in 1891. He died in 1920 in New Jersey. In 1927, the Celanese Corporation acquired the Celluloid Manufacturing Company, where it became a part of their plastics division. Since the 1950s, most billiard balls have been made of phenolic resin.

TIM PALUCKA

FOR FuRTHER READING: Susan Mossman, Ed., Early Plastics: Perspectives, 1850-1950 (Leicester University Press, London, 1997); Stephen Fenichell, Plastic, The Making of a Synthetic Century (HarperBusiness, New York, 1996); Polymer Pioneers (Center for History of Chemistry, Philadelphia, 1986); and Stephen L. Sass, The Substance of Civilization (Arcade Publishing, New York, 1998). 